\title{
A unique data set from southern Africa's mesic high-altitude fire climax grasslands: The Cathedral Peak experimental catchments from 1948 onwards
}

\author{
Michele Toucher ${ }^{1}$, Kent Lawrence ${ }^{1}$, Susan Janse van Rensburg ${ }^{1}$, and Paul Gordijn ${ }^{1}$ \\ ${ }^{1}$ South African Environmental Observation Network
}

October 1, 2020

\section{SITE DESCRIPTION}

The Cathedral Peak research catchments, which form part of a strategic water source area for South Africa, consist of ten (named I - X) well defined hydrological catchments, ranging in altitude from 1820 m.a.s.l to 2 463 m.a.s.l (Figure 1). The catchments fall within the summer rainfall region of South Africa, experiencing wet, humid summers and cold, dry winters (Everson et al ., 1998). The mean annual precipitation (MAP) for the area is approximately $1400 \mathrm{~mm}$ (Bosch, 1979), with $84 \%$ of this rainfall occurring between the months of October and March (Schulze, 1976). Half of the rainfall events in the catchments are thunderstorms (Schulze, 1976). Approximately $49 \%$ of the rainfall is converted to streamflow, with two thirds of the streamflow yield occurring during the four months from January to April (Bosch, 1979). The natural vegetation of the catchments is fire-adapted montane grassland, dominated by the grass (Themeda triandra). Woody communities dominated by Leucosidea sericea and Buddleia salvifolia occur in narrow, fire-protected zones along the streams in some catchments (Bosch, 1979).

Figure 1

\section{HISTORICAL MONITORING IN THE CATHEDRAL PEAK RESEARCH CATCH- MENTS}

Historically, the Mike's Pass station $(1948$ - 1994) was the primary meteorological station for the research catchments (Figure 1). In addition, precipitation was monitored at twenty-five sites across catchments I - X. Both 5" Snowdon rain gauges with Nipher shields and $5 \& 1 / 16$ " Casella Snowdon recording rain gauges were used. Streamflow monitoring was initiated in Catchments I - IX during the late 1940's and 1950's, and Catchment X during the 1960's. At the outlet of each catchment a concrete weir and stilling hut, with 90 degree V Notches, 18 inches deep, surmounted by 6 feet wide rectangular notches of varying depth (Meyburgh et al., 1970) made of brass were installed. The stilling ponds were dug to bedrock and rock walls for the pond were constructed. Details of how early measurements were taken, error checked and processed are given in Myeburgh et al. (1970). When cleaning the weirs, qualitative observations on the volume of silt removed from the weirs were made for selected catchments. Water chemistry sampling was initiated in Cathedral Peak in 1981, samples were analysed for $\mathrm{Na}^{+}, \mathrm{K}^{+}, \mathrm{Ca}^{+}, \mathrm{Mg}^{+}, \mathrm{Cl}^{-}, \mathrm{SO}_{4}{ }^{2-}, \mathrm{HCO}_{3}$, $\mathrm{NH}_{4}{ }^{+}, \mathrm{PO}_{4}{ }^{3-}, \mathrm{NO}_{3}{ }^{-}$, TP (Total Phosphorus), $\mathrm{KN}, \mathrm{Si}$ and $\mathrm{F}$. The $\mathrm{pH}$ and conductivity levels were assessed on site. A wealth of data has been collected for the Cathedral Peak research catchments, with the Council for Scientific and Industrial Research (CSIR) being the custodian of the hydrological and climatological data sets until SAEON's involvement in the catchments from 2012 onwards.

\section{CURRENT RESEARCH PLAN, MONITORING AND DATA}

Water is considered one of South Africa's potentially key limiting factors for economic development. Falling 
within a strategic water source, the Cathedral Peak Long-Term Ecological Research (LTER) platform is unique in that it is the only high-altitude hydroclimatic monitoring site in the southern African region. Thus, addressing the need for quality, long-term datasets and process level understanding in sensitive highaltitude areas, which are needed to improve the understanding of global change impacts on the ecosystem to ensure water security and provision to lower lying areas.

The hydro-climatological monitoring network was designed to be comparable with the historical network to benefit from the historic data for environmental change research as well as being relevant for monitoring changes and thresholds or tipping points in system behaviour into the future. Comparison studies between historical and current monitoring equipment have been undertaken (Gray and Toucher, 2019). More intensive monitoring is undertaken in Catchment VI, a near 'pristine' grassland catchment which is considered as the core, benchmark catchment as well as in Catchment III which is degraded and fire-protected Catchment IX which has become encroached with woody species.

\subsection{Climatological monitoring}

An automatic weather station (AWS) was installed at the old Mike's Pass meteorological site (1860 m.a.s.l) in August 2012. At this site, the core climatological parameters of solar radiation (CMP3, Kipp \& Zonen, Delft, The Netherlands), wind speed and direction (Model 03002, R.M. Young, Traverse city, Michigan, USA), air temperature and humidity (CS215, Campbell Scientific Inc., Logan, Utah, USA), rainfall (TR525, Texas Electronics Inc., Dallas, Texas, USA) are monitored. The climatic data are averaged over 5-min intervals from observations made every $10 \mathrm{~s}$ and stored on a datalogger (CR1000, Campbell Scientific Inc., Logan, Utah, USA). The rain gauge orifice is at $1.2 \mathrm{~m}$ above the ground and all other sensors are located $2 \mathrm{~m}$ above the ground. Two additional rain gauges (TR-525, Texas Electronics Inc., Dallas, Texas, USA with a Hobo Pendant Event loggers UA-003-64, MA, USA) are installed at the site as well as a groundlevel rain gauge designed to World Meteorological Organisation specifications, to ensure the quality of the rainfall record. Fog is monitored using a Juvick type gauge. Barometric pressure (PTB110, Viasala, Vantaa, Helsinki, Finland) and ground surface temperature (T107L, Campbell Scientific Inc., Logan, Utah, USA) are also recorded. Two additional AWS, one at a higher altitude of 3010 m.a.s.l (Vulture's retreat) and another at a lower altitude of 1367 m.a.s.l (OIC Research office), measure the same core climatological parameters as the Mike's Pass AWS.

Through Catchments I - X, twenty-three rain gauges (TR-525, Texas Electronics Inc., Dallas, Texas, USA with a Hobo Pendant Event loggers UA-003-64, MA, USA), at a standard height of $1.2 \mathrm{~m}$, have been installed at the sites where the historic rain gauges were located.

\subsection{Energy balance and carbon flux monitoring}

Fluxes and the energy balance are monitored in the near pristine Catchment VI with a full open path eddy covariance (EC) system (OPEC, Campbell Scientific Inc., Logan, Utah, USA), and alongside this soil respiration is monitored with a Li-Cor8100 equipped with eight chambers. Complimented by monthly soil respiration measurements across Catchment III and IX using cost effective techniques. A Large Aperture Scintillometer was installed for a short period in Catchment VI as well. The energy balance components are monitored in Catchments III and IX for use in the Surface Renewal method to solve for total evaporation.

\subsection{Hydrological and soil water monitoring}

Streamflow monitoring has resumed at the outlets of catchments III, IV, V, VI, VII and IX. The original weirs and stilling huts were repaired, and water stage-height is monitored using an Orpheus Mini (Ott Hydromet GmbH, Germany) at weirs IV, V, VI and VII, and CS451 Stainless steel SDI-12 Pressure Transducers and with CR200 loggers at weirs III, VI and IX. The two pressure transducers installed at weir VI are to ensure the quality of streamflow records from the core catchment. Water quality measurements of EC, TDS, PH, DO, ORP and temperature are taken on a monthly basis using a YSI Professional Plus multi-probe at each of the monitored weirs, including water sample collections for DOC. Soil water is monitored continuously in Catchment VI using a Cosmic Ray Probe for spatial soil water and CS616 Water Content Reflectometers 
installed to a depth of $1.4 \mathrm{~m}$ at the EC tower. In Catchments III and IX soil water is monitored using CS616 Water Content Reflectometers at the site of the energy balance measurements. Complementary spatially distributed, monthly measurements of soil water are made using a Diviner 2000 (Sentek). Soil surveys have been undertaken as well.

\section{CONTRIBUTIONS AND APPLICATIONS OF THE DATA}

The catchments have been instrumental in the development of South Africa's hydrological and ecological research, and have provided the evidence base for much of the country's water, forestry and environmental policy. In particular, the data from the catchments has contributed to the understanding of the impacts of afforestation on water yield (e.g. Nänni, 1970a, b; Bosch 1979; van der Zel, 1995, Scott \& Smith, 1997) hydrological model development (Schulze, 1976; Schulze, 1995) and understanding the impacts of fire on streamflow (Nänni, 1960; Bosch et al ., 1984; Van Wyk, 1986). The historical data collected for the site was consistent and of high quality until 1985 when funding for the monitoring became constrained. Due to the data gap between 1991 and 2012 and the short record since monitoring resumed, no trend analysis has been undertaken. However, the monthly rainfall and streamflow records expressed as an anomaly from the monthly means of the historical period $(1951$ - 1980) indicate that the contemporary period has been drier than the historical records (Figure 2). The 2018/2019 summer was one of the driest summers on record for Mike's Pass meteorological station.

\section{Figure 2}

The Cathedral Peak catchments fall within the Northern Drakensberg Strategic Water Source Area which generates $4.94 \%$ of South Africa's mean annual runoff (Le Maitre et al., 2018). Being the only high altitude monitored catchments on the eastern escarpment, the long term data from these catchments is of paramount importance in determining the impacts of environmental change on the ability of the area to supply water resources. The historic and contemporary records from these catchments provide data from Africa, which is often difficult to access even locally, and is scarcely represented in global analyses and international insights inferences that seek to influence policy and practice that affect Africa. Improving access to and inclusion of the African data and insights that are contextually relevant is critical for the development of locally beneficial policy and practice, and avoids negative outcomes of well-intended policies based on data from elsewhere.

\section{DATA AVAILABILITY}

The Cathedral Peak research catchments have been registered as LTER site (https://deims.org/495a527c4b57-4daa-b783-9b1e016dbaec) and SAEON is focused on ensuring the longevity and quality of the data. The Mike's Pass AWS can be viewed athttp://gfw.dirisa.org/weather/mikes-pass-weatherstationand the higher altitude station athttp://gfw.dirisa.org/weather/vultures-retreat-weatherstation. The contemporary daily precipitation (https://doi.org/10.15493/SAEON.GFW.10000002), streamflow (https://doi.org/10.15493/SAEON.GFW.10000007), and fog (https://doi.org/10.15493/SAEON.GFW.10000009) records are publicly available. The data will be made publicly accessible, through the SAEON Observations Database (https://observations.saeon.ac.za/) which is still under development. Specific project based data will be made publicly available following an embargo period.

\section{References}

Bosch, J M. (1979). Treatment effects on annual and dry period streamflow at Cathedral Peak. South African Forestry Journal,108(1), 29-38.

Bosch, J M., Schulze, R E. \& Kruger, F J. (1984). The effect of fire on water yield. In Booysen, J de V. \& Tainton, N M. (Eds), The Ecological Effects of Fire in South African Ecosystems . Springer, Berlin.

Everson, C E., Molefe, G L.\& Everson, T M. (1998) Monitoring and modelling components of the water balance in a grassland catchment in the summer rainfall area of South Africa. Water Research Commission, RSA, Report 493/1/98. 
Gray, B. \& Toucher, M L. (2019). Rain gauge accuracy at a high-altitude meteorological station in Cathedral Peak. Journal of Hydrologic Engineering , 24 (2), 04018064.

Nänni, U W. (1960). The immediate effects of veld-burning on streamflow in Cathedral Peak catchments. Journal of the South African Forestry Association , 34(1), 7-12.

Nänni, U W. (1970a). The effect of afforestation on streamflow at Cathedral Peak: Report No. 1. South African Forestry Journal , 74(1), 6-12.

Nänni, U W. (1970b). Trees, water and perspective. South African Forestry Journal , 75(1), 9-17.

SAEON Grasslands-Forests-Wetlands Node. (2020). Cathedral Peak research catchments Mike's Pass Station Fog Data [Data set]. South African Environmental Observation Network. https://doi.org/10.15493/SAEON.GFW.10000009

SAEON Grasslands-Forests-Wetlands Node. (2020). Cathedral Peak research catchments contemporary daily rainfall dataset [Data set]. South African Environmental Observation Network. https://doi.org/10.15493/SAEON.GFW.10000002

SAEON Grasslands-Forests-Wetlands Node. (2020). Cathedral Peak research catchments contemporary daily streamflow dataset [Data set]. South African Environmental Observation Network. https://doi.org/10.15493/SAEON.GFW.10000007

Schulze, R E. (1975). Catchment evapotranspiration in the Natal Drakensberg. Unpublished PhD Thesis, University of Natal, Pietermaritzburg, South Africa. Pp 244.

Schulze, R E. (1976). On the application of trend surfaces of precipitation to mountainous areas. Water SA , 2(3), 110-118.

Scott, D F. \& Smith, R E. (1997). Preliminary empirical models to predict reductions in total and lowflows resulting from afforestation. Water $S A, 23,135-140$.

van der Zel, D W. (1995). Accomplishments and dynamics of the South African afforestation permit system. South African Forestry Journal, 172, 49-57.

Van Wyk, D B. (1986). The effects of catchment management on sediment and nutrient exports in the Natal Drakensberg. In Schulze, R E. (Ed), Proc. Second South African National Hydrology Symp., Pietermaritzburg, September 1985. Agricultural Catchments Res. Unit Rep. No. 22, Department of Agricultural Engineering, University of Natal, Pietermaritzburg, pp. 266 - 274.

\section{Figure Captions}

Figure 1: Location of the Cathedral Peak Research catchments, South Africa and the monitoring sites in the catchments

Figure 2: (a) Monthly rainfall from the Mike's Pass AWS and (b) Catchment VI streamflow records expressed as an anomaly from the monthly means of the historical period $(1951-1980)$ 

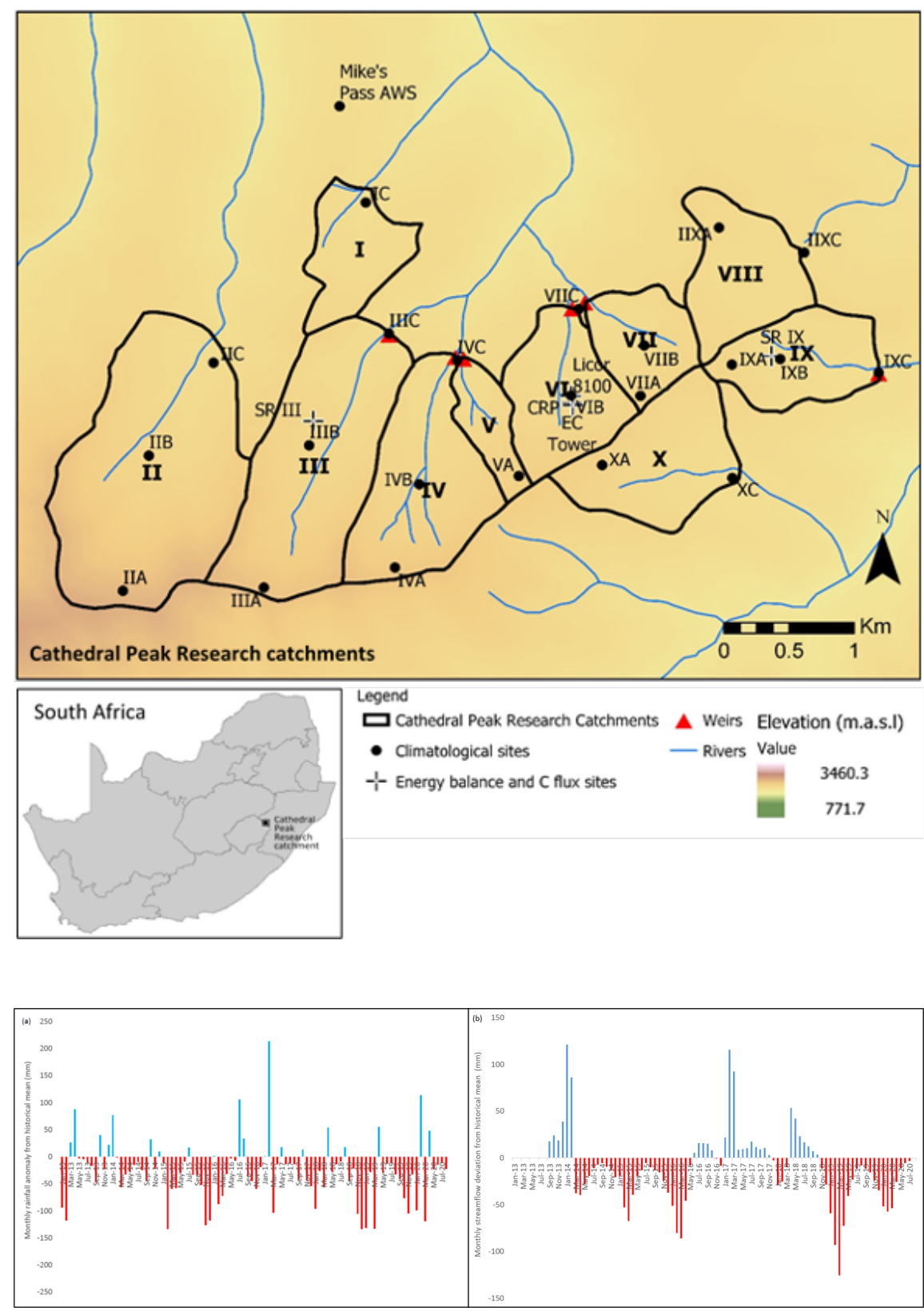